\title{
PERBEZAAN GENDER DALAM SOKONGAN PEMBELAJARAN DAN PENCAPAIAN AKADEMIK: PERANAN PERANTARA KETERLIBATAN MURID DI SEKOLAH
}

\section{GENDER DIFFERENCES IN LEARNING SUPPORT AND ACADEMIC ACHIEVEMENT: THE MEDIATING ROLE OF STUDENT ENGAGEMENT}

\author{
${ }^{1}$ Zalizan M. Jelas, ${ }^{2}$ Amla Salleh, ${ }^{3}$ Norzaini Azman, ${ }^{6}$ Rohana \\ Jani, ${ }^{7}$ Ramlah Hamzah, ${ }^{4}$ Izwan Mahmud, ${ }^{8}$ Zaleha Ab. Hamid, \\ ${ }^{9}$ Hanizah Hamzah, ${ }^{5}$ Hutkemri \\ 1, 2,3,4,5 Faculty of Education, Universiti Kebangsaan Malaysia \\ ${ }^{6}$ Faculty of Economics and Administration, Universiti Malaya \\ ${ }^{7}$ Faculty of Education and Human Development \\ Universiti Putra Malaysia \\ ${ }^{8}$ Educational Planning and Research Division \\ Ministry of Education Malaysia \\ ${ }^{9}$ Examination Board, Ministry of Education Malaysia
}

${ }^{1}$ Corresponding author: zmj@ukm.my

\begin{abstract}
ABSTRAK
Tujuan - Kajian ini bertujuan untuk meneliti perbezaan gender dalam sokongan pembelajaran, keterlibatan murid di sekolah dan pencapaian. Kajian ini juga meneliti sejauh mana keterlibatan tersebut berperanan sebagai perantara kepada gender, sokongan pembelajaran dengan pencapaian akademik.
\end{abstract}

Metodologi - Kajian ini menggunakan model keratan rentas yang melibatkan hubungan gender dengan keterlibatan murid di sekolah, sokongan pembelajaran dan pencapaian akademik. Sampel kajian adalah seramai 2,359 remaja lelaki dan perempuan berumur 12 hingga 16 tahun dari sekolah harian di kawasan bandar dan luar bandar. Instrumen Keterlibatan Murid di Sekolah dan Sokongan Pembelajaran digunakan untuk kutipan data. Kedua-dua instrumen telah diterjemah ke dalam bahasa Melayu untuk meninjau sejauh 
mana keterlibatan murid di sekolah dan persepsi mereka terhadap sokongan pembelajaran daripada ibu bapa, guru dan rakan sebaya. Kesahan dan kebolehpercayaan instrumen menunjukkan nilai tinggi. Analisis inferensi korelasi Pearson dijalankan untuk menentukan hubungan antara pemboleh ubah. Analisis model persamaan berstruktur (SEM) dilaksanakan untuk mengenal pasti peranan keterlibatan murid sebagai perantara gender dan sokongan pembelajaran terhadap pencapaian akademik.

Dapatan - Dapatan kajian menunjukkan bahawa tidak terdapat perbezaan gender yang signifikan dalam keterlibatan murid di sekolah, sokongan pembelajaran dan pencapaian akademik. Keterlibatan murid di sekolah merupakan perantara dalam hubungan gender dan pencapaian akademik. Keterlibatan murid di sekolah juga adalah perantara bagi sokongan guru, sokongan ibu bapa dan sokongan rakan sebaya terhadap pencapaian akademik.

Kepentingan - Dapatan kajian ini meneguhkan teori mengenai peranan dan sumbangan keterlibatan murid di sekolah, dan sokongan pembelajaran untuk meningkatkan pencapaian murid seperti mana kajian yang dilakukan di Barat terhadap konstruk yang dikaji. Dapatan kajian ini membantu menyediakan cadangan intervensi untuk meningkatkan sokongan pembelajaran dalam kalangan remaja.

Kata kunci: pencapaian akademik, perbezaan gender, keterlibatan murid di sekolah, sokongan guru, sokongan ibu bapa, sokongan rakan, analisis perantaraan.

\section{ABSTRACT}

Purpose - The study examined gender differences in perceived learning support, student engagement and academic achievement; and the mediation role of student engagement in the relationship of gender and learning support with achievement.

Methodology - The study is a cross-sectional survey to investigate the relationship between gender, student engagement, learning support and achievement. The sample consisted of 2,359 adolescents between the age of 12 and 16 years from rural and urban schools. 
The Student Engagement Scale was translated into Bahasa Malaysia with high validity and reliability. Inferential statistics using Pearson correlation was used to examine the relationship between variables. Structural equation modelling was used to identify the mediation role of student engagement.

Findings - There is no significant difference between gender and student engagement, learning support and achievement. Student engagement mediated both gender and learning support with achievement.

Significance - The results of this study support the findings of earlier studies conducted in western countries and reinforces the theory on the role of student engagement in enhancing achievement. The findings will help to prepare for interventions to support adolescent learning at different levels of schooling.

Keywords: Academic achievement, gender differences, student engagement, parental support, teacher support, peer support, mediation analysis.

\section{PENGENALAN}

Fenomena ketidakseimbangan pencapaian murid lelaki dibandingkan dengan murid perempuan merupakan satu fenomena global (CDEG, 2011; Ayodele, 2009; U.S.A.I.D., 2005; Epstein, Elwood, Jey \& Maw, 1998; MCEETYA, 1996) dan di Malaysia fenomena tersebut telah dikaji oleh beberapa orang pengkaji (Kementerian Pendidikan Malaysia, 2001; Nor Aniza, Zalizan \& Manisah, 2011). Analisis trend pencapaian murid mengikut jenis dan lokasi sekolah dalam peperiksaan awam pada tahun 2006 hingga 2011 menunjukkan secara konsisten jurang pencapaian murid lelaki dan perempuan, dan jurang di peringkat Sijil Peperiksaan Malaysia (SPM) adalah yang paling besar menyebelahi perempuan. Untuk mengatasi kesan negatif trend ketidakseimbangan pencapaian murid, adalah penting untuk mengenal pasti faktor-faktor yang menggalakkan kompetensi akademik terutama dalam kalangan murid lelaki supaya tindakan untuk meningkatkan kualiti prestasi sekolah dapat dilakukan.

Kajian lepas mengenai jurang pencapaian mengikut gender di Malaysia banyak menumpu kepada kesan gaya pembelajaran serta 
kemahiran dan strategi pembelajaran yang memihak kepada murid perempuan daripada lelaki (Zalizan, Saemah, Roselan \& Jamil, 2005; Zalizan \& Hazadiah, 2010). Gaya dan kemahiran belajar murid perempuan bersesuaian dengan gaya pengajaran guru perempuan serta persediaan untuk peperiksaan. Penelitian terhadap kesan gaya pembelajaran serta strategi untuk belajar dan hubungannya dengan pencapaian merupakan satu dimensi dalam usaha untuk mengenal pasti punca jurang pencapaian. Walaupun demikian, fenomena jurang pencapaian mengikut gender masih berterusan hingga kini, di mana ketidakseimbangan bilangan pelajar di peringkat pengajian tinggi menunjukkan enrolmen pelajar perempuan melebihi pelajar lelaki di universiti-universiti di Malaysia (Kementerian Pengajian Tinggi, 2012). Masih terdapat ruang untuk mengkaji fenomena tersebut dengan menggunakan pendekatan lebih komprehensif dan secara keratan rentas yang melibatkan sokongan pembelajaran (Bronfenbrenner, 1977; Benner, Graham \& Mistry, 2008) dan sejauh mana sokongan mempengaruhi pencapaian.

Sorotan kajian tentang keterlibatan murid di sekolah (Fredericks, Blumenfeld \& Paris, 2004; Furlong \& Christenson, 2008) dan sokongan pembelajaran daripada ibu bapa, guru dan rakan (Chen, 2005; Woolley \& Grogan-Kaylor, 2006) menunjukkan bahawa kedua konstruk adalah pemboleh ubah signifikan yang mempengaruhi pencapaian. Walaupun kajian lepas di luar negara telah membuktikan bahawa keterlibatan murid di sekolah dan sokongan pembelajaran adalah peramal penting kepada pencapaian sekolah (Li, Lerner \& Lerner 2010; Wang, Willett \& Eccles 2011; Lam, el at., 2012), artikel ini berusaha untuk meningkatkan kefahaman terhadap hubungan dan peranan kedua konstruk dalam konteks dan setting pendidikan di Malaysia.

\section{Jurang Gender dalam Keterlibatan Pelajar}

Dalam tahun-tahun kebelakangan ini, beberapa kajian telah menumpu kepada perbezaan gender dalam keterlibatan murid di sekolah serta komponen-komponen penting konstruk tersebut yang menerangkan kesan kepada pencapaian berbeza antara murid lelaki dan perempuan (Fall \& Robert, 2012; Wang \& Holcombe, 2010). Keterlibatan di sekolah murid lelaki adalah kurang daripada murid perempuan (Archambault, Janosz, Fallu, \& Pagani, 2009; Lam et al., 2012). Murid lelaki menunjukkan motivasi lebih rendah 
daripada murid perempuan dalam melengkapkan kerja rumah serta mempunyai jangkaan diri yang rendah serta tidak begitu bersemangat untuk menyambung pengajian ke peringkat lebih tinggi (Darom \& Rich, 1988; Warrington, Younger \& Williams, 2000). Dari aspek penglibatan dalam aktiviti akademik, murid lelaki tidak begitu cenderung untuk merancang, memantau dan mengawal aktiviti dan kemahiran belajar sebagaimana murid perempuan (Zalizan et al. 2005; Nor Aniza el at., 2011; Kenny-Benson, Pomerantz, Ryan \& Patrick, 2006).

Terdapat juga hasil kajian yang menunjukkan bahawa jurang pencapaian berdasarkan gender adalah berkait rapat dengan keterlibatan murid di sekolah. Dapatan kajian Freudenthaler, Spinath dan Neubauer (2008) mendapati bahawa motivasi intrinsik sekolah adalah lebih penting untuk berjaya di sekolah bagi murid lelaki jika dibandingkan dengan murid perempuan. Freudenthaler el at., (2008) telah merumuskan bahawa menyukai tugas-tugas yang dilakukan adalah penting bagi murid lelaki. Sebaliknya, murid perempuan mampu melakukan tugas-tugas yang mereka tidak suka. Oleh kerana kerja sekolah tidak selalu menyeronokkan dan menarik, keadaan tersebut merupakan satu kelebihan bagi murid perempuan. Murid perempuan mampu berusaha dan cekal dalam tugas walaupun tugas tersebut membosankan. Walaupun demikian, dapatan kajian Freudenthaler et al. (2008) bercanggah dengan dapatan kajian Steinmayr dan Spinath (2008) yang mendapati bahawa tiada perbezaan antara motivasi dan pencapaian sekolah berdasarkan gender. Kajian Ruban dan McCoach (2005) juga melaporkan bahawa tidak terdapat perbezaan dalam impak regulasi-kendiri dan faktor motivasi terhadap pencapaian berdasarkan gender. Pengkaji tersebut telah melakukan analisis pelbagai kumpulan dan mendapati tiada perbezaan fungsi peramal tersebut berdasarkan gender. Oleh kerana terdapat dapatan kajian yang bercanggah, kajian lanjutan perlu dilakukan untuk meninjau hubungan antara keterlibatan murid di sekolah dan prestasi akademik dalam kalangan murid lelaki dan perempuan.

\section{Keterlibatan Murid Di Sekolah}

Kajian empirikal telah membuktikan bahawa keterlibatan murid di sekolah adalah penting untuk meramal kejayaan akademik dan mengelakkan keciciran sekolah (Appleton, Christenson \& Furlong, 
2008; Finn \& Zimmer, 2012). Walaupun demikian, definisi keterlibatan murid di sekolah sebagai satu konstruk adalah berbeza di antara pengkaji. Finn (1989) mencadangkan bahawa keterlibatan murid di sekolah meliputi dua dimensi iaitu penyertaan (participation) dan pengenalan (identification), manakala Appleton, Christenson, Kim \& Reschly (2006) mencadangkan konstruk keterlibatan sebagai mempunyai empat komponen iaitu keterlibatan akademik, tingkah laku, kognitif dan afektif. Walaupun secara amnya terdapat persetujuan bahawa keterlibatan murid di sekolah mempunyai pelbagai dimensi, kebanyakan pengkaji bersetuju dengan konstruk keterlibatan yang dicadangkan oleh Fredericks, Blumenfeld dan Paris (2004) yang telah mengesyorkan bahawa keterlibatan murid mengandungi tiga dimensi iaitu keterlibatan tingkah laku, keterlibatan emosi, afektif dan keterlibatan kognitif. Fredericks et al. (2004) telah mendefinisikan keterlibatan tingkah laku sebagai bermaksud penyertaan murid dalam kegiatan pembelajaran yang mencerminkan usaha dan ketekunan serta penglibatan dalam aktiviti kokurikulum sekolah. Murid yang menunjukkan keterlibatan tingkah laku tinggi adalah aktif dalam aktiviti kelas dan menunjukkan kesungguhan untuk berjaya. Keterlibatan afektif merujuk kepada reaksi emosi seperti menunjukkan minat, bangga, bosan atau kebimbangan apabila belajar dalam kelas atau bila berada di sekolah. Murid yang menunjukkan minat dan motivasi tinggi terhadap sekolah dan pembelajaran adalah murid yang mempunyai keterlibatan afektif yang tinggi. Keterlibatan kognitif merujuk kepada strategi belajar murid yang melibatkan regulasi kendiri dan kemahiran metakognitif untuk merancang, memantau dan menilai kandungan yang dipelajari. Murid yang mempunyai keterlibatan kognitif tinggi mempamerkan kesediaan untuk menerima cabaran, fleksibel dalam menyelesaikan masalah dan menilai kerelevanan pembelajaran di sekolah sebagai persediaan hidup pada masa hadapan.

Dapatan beberapa kajian lepas (Chen 2005; Li, Lerner \& Lerner, 2010) telah menunjukkan bahawa keterlibatan murid di sekolah berperanan sebagai konstruk perantara yang menghubungkan sokongan pembelajaran dengan pencapaian akademik dan menunjukkan variasi mengikut sumber sokongan. Sebagai contoh, kajian Chen (2005) mendapati bahawa sokongan akademik ibu bapa, guru dan rakan dalam kalangan remaja Hong Kong mempengaruhi pencapaian mereka secara langsung dan tidak langsung melalui keterlibatan di sekolah. Sokongan guru adalah 
penyumbang paling tinggi terhadap pencapaian secara langsung dan secara tidak langsung melalui keterlibatan murid di sekolah. Chen menganalisis peranan perantara keterlibatan sebagai satu konstruk secara keseluruhan manakala dalam kajian Li et al. (2010) peranan perantara keterlibatan murid di sekolah dianalisis mengikut dua dimensi keterlibatan iaitu keterlibatan tingkah laku dan keterlibatan emosi. Maka, pengkaji mempunyai peluang untuk menguji sejauh mana setiap dimensi keterlibatan responsif terhadap variasi konteks atau pemboleh ubah yang dikaji.

Dalam kajian ini definisi keterlibatan murid di sekolah adalah sebagai satu konstruk tiga dimensi yang meliputi pelbagai proses keterlibatan tingkah laku, keterlibatan afektif dan keterlibatan kognitif. Peranan perantara keterlibatan murid di sekolah dianalisis secara keseluruhan dan analisis SEM digunakan untuk meninjau hubungan langsung dan tidak langsung antara sokongan pembelajaran dan keterlibatan murid di sekolah dengan pencapaian murid lelaki dan perempuan.

\section{Sokongan Pembelajaran}

Keterlibatan murid sebagai satu konsep bukan mencerminkan sifat individu murid malah merujuk kepada keadaan diri murid yang sentiasa dipengaruhi keluarga, sekolah dan rakan untuk mendapatkan jangkaan dan sokongan pembelajaran secara konsisten (Sharifah Azizah \& Rosna, 2011: Reschly \& Christenson, 2006, Roeser, Eccles \& Sameroff, 2000). Dapatan kajian telah membuktikan bahawa hubungan interpersonal, dinamika kumpulan keluarga dan rakan serta interaksi dalam proses pengajaran dan pembelajaran mempengaruhi secara langsung bagaimana dan mengapa murid berusaha untuk berjaya dalam akademik. Pendekatan sosioekologikal untuk menerangkan hubungan sokongan keluarga, sekolah dan rakan terhadap keterlibatan murid di sekolah dan pencapaian adalah diasaskan kepada hasil kerja beberapa orang ahli teoris seperti Bronfenbrenner (1989) dan Eccles (2007). Mengikut Bronfenbrenner, perkembangan manusia berlaku dalam susunan sistem-sistem dan sistem mikro merupakan persekitaran fizikal dan sosial dalam kehidupan seharian mereka sama ada di rumah, sekolah dan di kawasan kejiranan. Hubungan langsung dalam sistem mikro mempunyai kesan yang signifikan terhadap perkembangan kanakkanak dan remaja. Pendekatan sosioekologikal mengandaikan bahawa untuk mencapai kesepadanan antara keperluan murid dan 
jangkaan pembelajaran, matlamat jangkaan murid dan jangkaan sekolah perlu dinyatakan dengan jelas. Kajian ini meneliti tanggapan murid terhadap sokongan ibu bapa, sekolah dan rakan terhadap pembelajaran dengan andaian bahawa murid yang mempunyai tanggapan positif terhadap sokongan ibu bapa, sekolah dan rakan mempengaruhi secara positif keterlibatan mereka di sekolah dan pencapaian.

Kajian empirikal mengenai penglibatan ibu bapa dan gaya keibubapaan telah mengesahkan peranan ibu bapa sebagai penyumbang kepada keterlibatan di sekolah dan pencapaian anakanak mereka (Waanders, Mendez \& Downer, 2007; Bempechat \& Shernoff, 2012). Ibu bapa atau ahli keluarga yang menyediakan sokongan akademik, seperti bantuan dalam kerja sekolah di rumah, dan sokongan motivasi, seperti berbincang mengenai sekolah dan memantau kegiatan anak-anak, menyumbang kepada prestasi akademik anak mereka.

Kajian-kajian oleh Eccles el at., (1993), Furrer dan Skinner (2003), serta Roorda, Koomen, Spilt dan Oort (2011) telah menunjukkan konsensus bahawa interaksi positif guru-murid menyumbang kepada motivasi dan prestasi sekolah. Keanggotaan murid di dalam kelas dan di sekolah dapat diperkukuh jika guru memberi perhatian dan mengambil berat terhadap perasaan murid (Pianta, Hamre \& Allen, 2012; Croninger \& Lee, 2001). Peranan guru untuk mengenal pasti matlamat kurikulum dan menyediakan peluang untuk murid mengaitkan pembelajaran di sekolah dengan kehidupan harian secara peribadi dan minat mereka amat penting untuk murid lebih fokus dalam proses pengajaran dan pembelajaran (Hipkins, 2012; Assor, 2012).

Hubungan positif murid bersama rakan juga adalah aspek penting proses sosialisasi dan pendidikan murid selain ibu bapa dan guru. Kajian Wentzel $(1999 ; 2005 ; 2009)$ telah mengukuhkan bahawa mengekalkan hubungan positif bersama rakan memberi impak positif terhadap motivasi dan keterlibatan murid di sekolah. Sejauh mana murid merasakan penerimaan rakan atau sebaliknya dan sama ada persahabatan berasaskan rakan akademik atau emosi boleh mempengaruhi serta memotivasikan murid untuk lebih terlibat serta aktif dalam kegiatan akademik dan sekolah (Juvonen, Espinoza \& Knifsend, 2012). 


\section{TUJUAN KAJIAN}

Kajian ini bertujuan untuk meneliti perbezaan gender dalam keterlibatan murid di sekolah dan sejauh mana keterlibatan tersebut berkait dengan sokongan pembelajaran dan pencapaian akademik. Objektif pertama adalah untuk meninjau sama ada terdapat perbezaan tahap keterlibatan murid di sekolah dan sama ada terdapat perbezaan persepsi sokongan ibu bapa, guru dan rakan sebaya dalam kalangan murid lelaki dan perempuan. Objektif kedua adalah untuk meneliti sama ada perbezaan gender dalam keterlibatan murid di sekolah menerangkan jurang gender dalam pencapaian. Objektif ketiga adalah untuk meneliti sejauh mana keterlibatan murid di sekolah berperanan sebagai perantara kepada sokongan pembelajaran dan pencapaian akademik.

Data dalam kajian ini adalah sebahagian daripada data kajian yang lebih besar bertajuk Analisis Gender Dalam Pendidikan di bawah geran penyelidikan Kementerian Pengajian Tinggi. Kajian tersebut melibatkan banyak pemboleh ubah untuk mengkaji prestasi pendidikan antara murid lelaki dan perempuan di peringkat pendidikan asas dan pelajar di institusi pengajian tinggi. Artikel ini hanya menumpu kepada sejauh mana konstruk keterlibatan murid di sekolah dapat menerangkan hubungannya dengan sokongan pembelajaran dan pencapaian akademik supaya perancangan strategik untuk mengatasi kemunduran pencapaian bukan sahaja dalam kalangan murid lelaki tetapi juga dalam kalangan murid perempuan.

Dengan menggunakan kaedah sepertimana kajian Lam et al. (2012) yang mengkaji peranan keterlibatan murid di sekolah berdasarkan gender di 12 negara, kajian ini melibatkan sampel murid di Malaysia untuk menguji sama ada dapatan yang diperoleh dapat menyokong kajian Lam et al. (2012) dan kajian lain di luar negara. Maka, dapatan kajian ini menguji teori terhadap peranan keterlibatan murid di sekolah sebagai perantara gender, sokongan pembelajaran dan pencapaian berdasarkan latar belakang pendidikan di Malaysia supaya implikasi dan cadangan amalan bersesuaian dengan konteks dan budaya Malaysia. 


\section{METODOLOGI}

\section{Sampel}

Responden dalam kajian ini adalah dari populasi golongan remaja lelaki dan perempuan sekolah berumur antara 12 hingga 16 tahun. Pemilihan sampel dilakukan melalui kaedah persampelan rawak berstrata berdasarkan tahun persekolahan, gender dan lokasi (bandar dan luar bandar) sekolah harian. Murid dari sekolah berasrama penuh dan murid dari program pendidikan khas tidak termasuk dalam kajian ini. Bilangan sampel murid lelaki adalah 1,170 orang dan sampel perempuan adalah 1,189 orang. Jumlah keseluruhan sampel kajian adalah 2,359 .

\section{Instrumen}

Soal selidik dan konstruk keterlibatan murid di sekolah dan sokongan pembelajaran yang digunakan dalam kajian ini diterjemah dari School Engagement Scale (Lam et al. 2012). Instrumen tersebut terdiri dari tiga bahagian yang diukur berdasarkan skala likert lima tahap seperti berikut:
A. Maklumat demografi (6 item)
B. Keterlibatan sekolah (33 item)
i. Keterlibatan afektif (9 item)
ii. Keterlibatan tingkahlaku (12 item)
iii. Keterlibatan kognitif (12 item)
C. Persepsi terhadap sokongan (14 item)
i. Sokongan guru (3 item)
ii. Sokongan rakan sebaya (3 item)
iii. Sokongan ibu bapa (8 item)

Instrumen kajian telah diterjemahkan melalui proses penterjemahan berikut:

i. Menterjemah daripada Bahasa Inggeris ke Bahasa Melayu dan penterjemahan semula ke Bahasa Inggeris (back translation);

ii. Pengesahan tiga orang panel pakar terhadap kesesuaian terjemahan dan penterjemahan semula item; 
Pentadbiran ujian dan ujian semula (test-retest) soal selidik melibatkan 20 orang murid yang fasih dalam Bahasa Melayu dan Bahasa Inggeris. Murid dibahagikan kepada dua kumpulan: Kumpulan 1 (10 orang murid) memberi respon kepada soal selidik versi Bahasa Melayu dan kumpulan 2 (10 orang murid lain) memberi respon kepada versi Bahasa Inggeris. Selepas seminggu, kedua kumpulan murid di uji semula, kumpulan 1 menggunakan versi Bahasa Inggeris dan kumpulan 2 diuji menggunakan versi Bahasa Melayu. Kebolehpercayaan terjemahan soalselidik adalah tinggi: nilai korelasi split half antara versi Bahasa Melayu dan versi Bahasa Inggeris adalah 0.73; manakala hasil analisis Cronbach Alpha bagi konstruk keterlibatan murid di sekolah adalah 0.85 dan bagi sokongan guru adalah 0.81 , sokongan ibu bapa adalah 0.75 dan sokongan rakan sebaya adalah 0.68 . Pencapaian akademik diperoleh dari nilai purata gred murid dalam semua mata pelajaran di sekolah. Nilai purata gred murid telah ditukar kepada skala tiga mata: $1=$ rendah, $2=$ sederhana dan $3=$ tinggi.

\section{Analisis Data}

Bagi objektif kajian pertama, analisis deskriptif yang melibatkan min dan sisihan piawai digunakan untuk meneliti sama ada murid lelaki dan perempuan menunjukkan tahap berbeza dalam keterlibatan di sekolah dan sama ada mereka mempunyai persepsi berbeza terhadap sokongan guru, ibu bapa dan rakan. Kesan saiz perbezaan antara kedua gender terhadap pemboleh ubah tersebut turut dilakukan. Analisis SEM digunakan untuk menentukan sama ada perbezaan gender dalam keterlibatan murid di sekolah dan sokongan pembelajaran murid menerangkan jurang pencapaian mereka, analisis pengantaraan telah dilakukan untuk meneliti kesan pengantaraan keterlibatan murid di sekolah terhadap kaitan antara gender dan pencapaian. Selain itu, analisis pengantaraan juga digunakan bagi menentukan keterlibatan murid di sekolah sebagai perantara sokongan guru, ibu bapa dan rakan terhadap pencapaian akademik. Kajian ini menggunakan indeks ukuran padanan yang selalu digunakan sebagai penanda aras dalam menentukan kebagusuaian padanan sesuatu model, antaranya root mean-square error of approximation (RMSEA), comparative fit index (CFI) dan normed chi-square $(\chi 2 / \mathrm{df})$ (Hair, Black, Babin, Anderson \& Tatham, 2006). 


\section{DAPATAN KAJIAN}

\section{Perbezaan Gender Berdasarkan Pemboleh Ubah}

Jadual 1 membentangkan statistik deskriptif kelima-lima pemboleh ubah berdasarkan gender. Secara keseluruhan, murid perempuan mempunyai skor lebih tinggi daripada murid lelaki. Perbezaan yang ketara adalah pada pembolehubah sokongan rakan. Untuk menilai sama ada perbezaan min antara gender adalah signifikan, analisis Cohen $d$ telah dilakukan untuk menentukan kesan saiz. Nilai Cohen $d$ secara keseluruhannya adalah di tahap rendah (Kelley $\&$ Preacher, 2012). Nilai Cohen $d$ bagi setiap pemboleh ubah adalah seperti berikut: sokongan guru (.004); sokongan ibu bapa (.002); sokongan rakan sebaya (.033); keterlibatan murid (.008) dan pencapaian (.005). Hal ini menunjukkan perbezaan tersebut adalah tidak signifikan.

Jadual 1

Min dan Korelasi antara Pemboleh Ubah bagi Pelajar Lelaki dan Perempuan

\begin{tabular}{|c|c|c|c|c|c|c|c|c|}
\hline & $\begin{array}{c}\mathrm{L} \\
(\mathrm{n}=1170)\end{array}$ & $\begin{array}{c}\mathrm{P} \\
(\mathrm{n}=1189)\end{array}$ & Cohen's d & 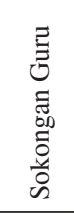 & 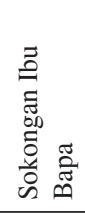 & 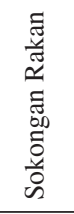 & 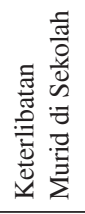 & 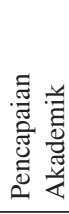 \\
\hline 1. Sokongan Guru & $\begin{array}{c}3.55 \\
(0.94)\end{array}$ & $\begin{array}{c}3.67 \\
(0.90)\end{array}$ & 0.004 & 1 & $.42 * *$ & $.33 * *$ & $.56 * *$ & .05 \\
\hline 2. Sokongan Ibu Bapa & $\begin{array}{l}3.94 \\
(0.70)\end{array}$ & $\begin{array}{c}4.00 \\
(0.73)\end{array}$ & 0.002 & $.46^{* *}$ & 1 & $.36^{* *}$ & $.54 * *$ & $.01 * *$ \\
\hline 3. Sokongan Rakan & $\begin{array}{c}3.93 \\
(0.82)\end{array}$ & $\begin{array}{c}4.22 \\
(0.79)\end{array}$ & 0.033 & $.35 * *$ & $.30 * *$ & 1 & $.33 * *$ & $.10 * *$ \\
\hline $\begin{array}{l}\text { 4. Keterlibatan Murid } \\
\text { di Sekolah }\end{array}$ & $\begin{array}{l}3.72 \\
(0.57)\end{array}$ & $\begin{array}{l}3.82 \\
(0.55)\end{array}$ & 0.008 & $.50 * *$ & $.58 * *$ & $.26 * *$ & 1 & $.11 * *$ \\
\hline $\begin{array}{l}\text { 5. Pencapaian } \\
\text { Akademik }\end{array}$ & $\begin{array}{c}2.18 \\
(0.77)\end{array}$ & $\begin{array}{c}2.29 \\
(0.74)\end{array}$ & 0.005 & $.11 * *$ & $.11 * *$ & $.10 * *$ & $.19 * *$ & 1 \\
\hline
\end{tabular}

Nota Nilai koefisien bagi korelasi di atas garisan pepenjuru adalah untuk murid lelaki manakala nilai koefisien bagi korelasi di bawah garisan pepenjuru adalah untuk murid perempuan. $* * \mathrm{p}<.01, * \mathrm{p}<.05$ 


\section{Kesan Keterlibatan Murid di Sekolah sebagai Perantara Gender terhadap Pencapaian Akademik}

Untuk menguji sama ada keterlibatan murid di sekolah menunjukkan kesan perantara dalam hubungan gender dan pencapaian, analisis perantaraan menggunakan SEM telah dilakukan. Keputusan analisis laluan model persamaan SEM menunjukkan ukuran Chi Square/ df $=0.00$, Root Mean Square Error Approximation $($ RMSEA $)=0.02$, Goodness of Fit Index $(G F I)=1.00$ dan Comparative Fit Index $(\mathrm{CFI})=1.00$. Kesemua jenis ukuran penilaian yang digunakan menunjukkan bahawa data yang digunakan dalam kajian ini terbukti mempunyai penyesuaian munasabah bagi model yang dicadangkan (Byrne, 2010).

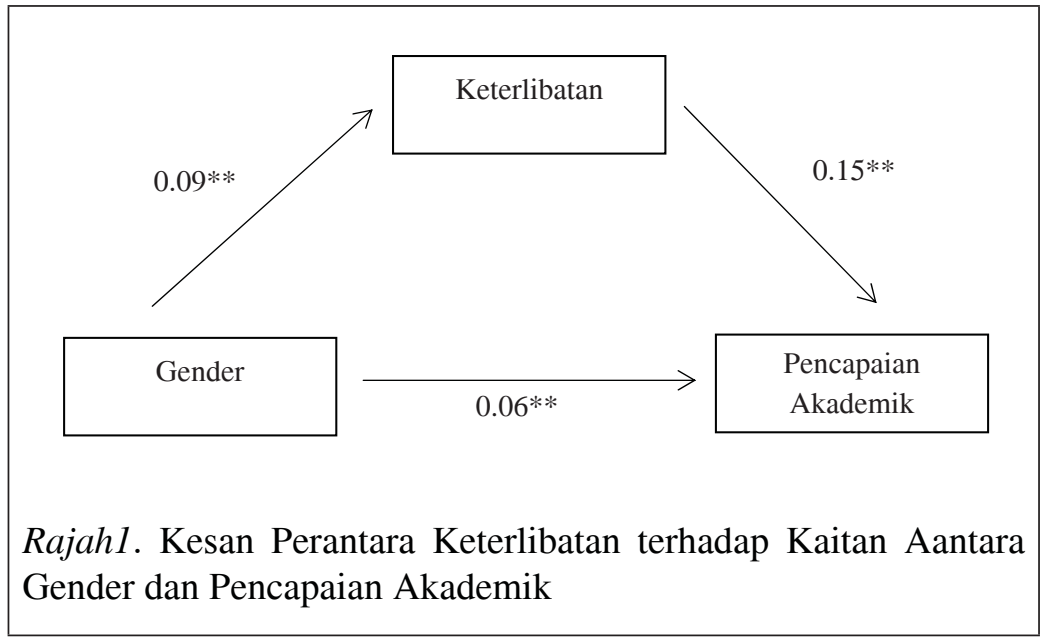

Rajah 1 menunjukkan kesan perantara keterlibatan murid di sekolah antara gender dan pencapaian akademik. Tiga keperluan untuk melaksanakan analisis perantaraan seperti yang dicadangkan Baron dan Kenny (1986) serta Hays (2009) telah dijalankan. Pertama, pemboleh ubah bebas (i.e. gender) meramal secara signifikan pemboleh ubah bersandar (i.e. pencapaian). Kesan keseluruhan gender ke atas pencapaian adalah signifikan $(\beta=0.06, \mathrm{p}<0.05)$. Murid perempuan menunjukkan pencapaian yang lebih baik. Kedua, pemboleh ubah bebas (i.e. gender) meramal secara signifikan pemboleh ubah bersandar (i.e. keterlibatan murid di sekolah). Kesan keseluruhan gender ke atas keterlibatan murid di sekolah adalah signifikan $(\beta=.09, \mathrm{p}<0.05)$. Murid perempuan menunjukkan 
keterlibatan yang lebih tinggi. Ketiga, secara keseluruhannya pemboleh ubah perantara (i.e. keterlibatan murid di sekolah) secara signifikan meramal pemboleh ubah bersandar (i.e. pencapaian) ( $\beta$ $=0.15, \mathrm{p}<0.05)$. Keterlibatan murid di sekolah meramal secara signifikan pencapaian setelah pemboleh ubah gender dikawal. Hasil ujian Sobel untuk meneliti kesan pengantaraan menunjukkan keputusan yang signifikan, $\mathrm{z}=3.91(\mathrm{p}<0.05)$. Dapatan ujian Sobel ini mengukuhkan lagi bahawa keterlibatan merupakan perantara gender terhadap pencapaian akademik. Secara langsung kesan gender terhadap pencapaian akademik adalah signifikan $(\mathrm{Ed}=0.086$, $\mathrm{p}<0.05)$. Secara tidak langsung kesan gender terhadap pencapaian akademik melalui perantara keterlibatan murid adalah tidak besar, namun signifikan $(\mathrm{Ei}=0.025, \mathrm{p}<0.05)$.

\section{Kesan Keterlibatan sebagai Perantara Sokongan Ibu Bapa, Guru dan Rakan terhadap Pencapaian Akademik Pelajar}

Rajah 2 menunjukkan sumbangan sokongan pembelajaran, iaitu sokongan ibu bapa, guru dan rakan terhadap keterlibatan murid di sekolah dan pencapaian. Dapatan analisis model persamaan berstruktur menunjukkan nilai-nilai indeks adalah sepadan antara model dengan data sampel iaitu ukuran Chi Square/ $\mathrm{df}=0.00$, nilai Root Mean Square of Error Approximation $($ RMSEA $)=0.03, \mathrm{p}<0.00$; nilai Goodness of Fitness Index $(G F I)=0.99$; dan Comparative Fit Index $(C F I)=0.99)$. Secara keseluruhannya, hasil penilaian menunjukkan bahawa terdapat kesepadanan yang baik antara model dengan data dalam sampel kajian ini dan selanjutnya penilaian tentang setiap pekali koefisien dijalankan. Laluan koefisien yang signifikan menunjukkan terdapat hubungan yang signifikan antara pemboleh ubah yang dinyatakan.

Berdasarkan Rajah 2, antara tiga sumber, sokongan ibu bapa memberi kesan langsung yang paling tinggi terhadap keterlibatan di sekolah $(\beta=0.39, \mathrm{p}<0.05)$ dan diikuti oleh sokongan guru $(\beta=0.34$, $\mathrm{p}<0.05)$. Sokongan guru dan sokongan ibu bapa juga memberi kesan tidak langsung yang positif kepada pencapaian akademik melalui keterlibatan di sekolah. Sementara itu, sokongan rakan memberi kesan langsung kepada pencapaian; manakala sokongan guru dan sokongan ibu bapa tidak memberi kesan secara langsung kepada pencapaian. Dapatan ini memberi impak bahawa guru dan ibu bapa 
memainkan peranan amat penting dalam memberikan sokongan meningkatkan keterlibatan murid di sekolah dan keterlibatan pula merupakan perantara sokongan pembelajaran murid dengan pencapaian akademik $(\beta=0.14, \mathrm{p}<0.05)$.

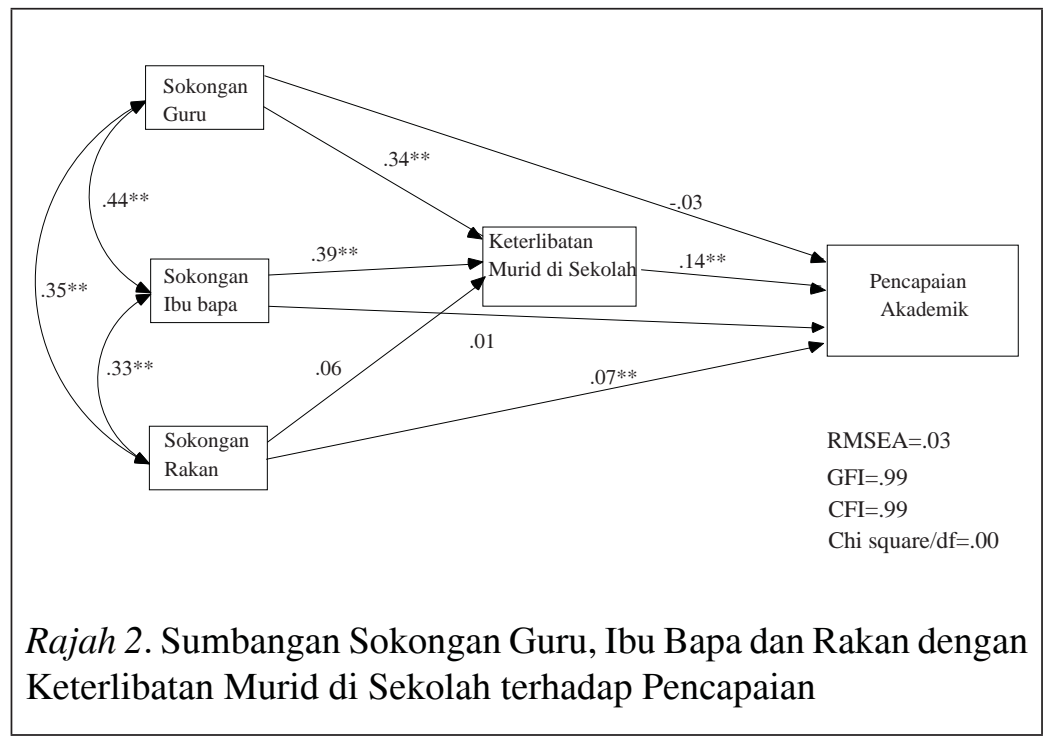

Analisis ujian Sobel dijalankan untuk melihat kesan keterlibatan murid sebagai perantara yang signifikan bagi setiap aspek dalam sokongan pembelajaran murid. Jadual 2 menunjukkan bahawa keterlibatan murid merupakan perantara yang signifikan bagi sokongan guru $(\mathrm{z}=1.87, \mathrm{p}<0.05)$, sokongan ibu bapa $(\mathrm{z}=7.62$, $\mathrm{p}<0.05)$ dan sokongan rakan sebaya $(\mathrm{z}=6.94, \mathrm{p}<0.05)$ terhadap pencapaian akademik.

Jadual 2

Ujian Sobel Kesan Keterlibatan Murid di Sekolah sebagai Perantara Sokongan Pembelajaran Murid terhadap Pencapaian Akademik Pelajar

\begin{tabular}{lcc}
\hline \multicolumn{1}{c}{ Perantara } & $\mathrm{Z}$ & $\mathrm{P}$ \\
\hline Sokongan guru $\rightarrow$ Keterlibatan murid $\rightarrow$ Pencapaian & 1.87 & 0.03 \\
Sokongan ibu bapa $\rightarrow$ Keterlibatan murid $\rightarrow$ Pencapaian & 7.62 & 0.00 \\
Sokongan rakan sebaya $\rightarrow$ Keterlibatan murid $\rightarrow$ Pencapaian & 6.94 & 0.00 \\
\hline
\end{tabular}


Secara langsung kesan sokongan rakan sebaya terhadap pencapaian murid adalah signifikan $(\mathrm{Ed}=0.68, \mathrm{p}<0.05)$. Secara tidak langsung kesan sokongan rakan terhadap pencapaian murid melalui perantara keterlibatan murid di sekolah adalah signifikan $(\mathrm{Ei}=0.008, \mathrm{p}<0.05)$. Walau bagaimanapun, secara langsung sokongan guru $(\mathrm{Ed}=-0.022$, $\mathrm{p}>0.05)$ dan ibu bapa $(\mathrm{Ed}=0.015, \mathrm{p}>0.05)$ adalah tidak signifikan. Secara tidak langsung, sokongan guru $(\mathrm{Ei}=0.039, \mathrm{p}<0.05)$ dan sokongan ibu bapa $(\mathrm{Ei}=0.058, \mathrm{p}<0.05)$ melalui perantara keterlibatan murid di sekolah memberikan sumbangan yang signifikan.

\section{KESIMPULAN}

Berdasarkan tiga objektif kajian ini, analisis data menunjukkan dapatan berikut. Pertama, jika dibandingkan dengan murid lelaki, murid perempuan menunjukkan min keterlibatan di sekolah dan pencapaian akademik yang lebih baik. Mereka juga mempunyai persepsi lebih tinggi terhadap sokongan guru, ibu bapa dan rakan. Walaupun demikian, perbezaan tersebut tidak signifikan dan kesan saiz adalah kecil. Kedua, keterlibatan murid adalah perantara dalam hubungan antara gender dan pencapaian akademik. Sebagai perantara, keterlibatan murid menerangkan perbezaan dalam pencapaian akademik walaupun kesan perantaraan tidak begitu besar. Akhir sekali, hasil analisis SEM menunjukkan bahawa terdapat kesepadanan yang baik antara model dengan data dalam sampel kajian. Sokongan ibu bapa menunjukkan kesan langsung paling tinggi, diikuti sokongan guru terhadap keterlibatan murid di sekolah; dan memberi kesan tidak langsung kepada pencapaian melalui keterlibatan murid di sekolah walaupun sokongan guru tidak memberi kesan langsung kepada pencapaian.

Penemuan di atas tidak konsisten dengan kajian Lam et al. (2012) dan Chen (2005) yang mendapati bahawa terdapat perbezaan signifikan. Dalam kajian Lam et al. (2012), pencapaian diukur melalui kedudukan murid yang ditentukan oleh guru manakala dalam kajian ini pencapaian adalah berdasarkan purata gred sebenar yang diperoleh dari sekolah. Kedudukan yang ditentukan oleh guru mungkin dipengaruhi oleh persepsi guru terhadap gender yang memberi kesan terhadap perbezaan pencapaian (Freudenthaler et al., 2008). Sebagai contoh, guru memberi kedudukan pencapaian yang tinggi kepada murid perempuan kerana murid perempuan 
lebih patuh kepada arahan dan memenuhi jangkaan guru berbanding murid lelaki.

Kajian Lam et al. (2012) dengan beberapa kajian lain menggunakan kaedah sama untuk mengukur perbezaan gender (Ryan, 2001; Chen, 2005). Kajian tersebut mendapati terdapat perbezaan gender dan hubungannya dengan keterlibatan murid, sokongan pembelajaran serta pencapaian. Kajian dengan menggunakan kaedah yang tidak sama memberikan hasil yang tidak konsisten (Gerber, Finn, Achilles \& Zaharias 2001; Dee, 2007; Ding \& Lehrer, 2007). Kajian akan datang perlu menyiasat sejauh mana terdapat perbezaan atau tidak mengikut gender dan hubungannya dengan pemboleh ubah terhadap pencapaian.

Sokongan rakan sebaya merupakan faktor yang memberikan sumbangan langsung kepada pencapaian murid. Hal ini menunjukkan bahawa murid lebih mempercayai rakan sebaya untuk membantu mereka dalam pembelajaran. Sikap rakan sebaya yang mengambil berat keadaan murid menggalakkan mereka untuk hadir dan aktif dalam aktiviti sekolah. Konsisten dengan kajian Darensbourg dan Blake (2014) yang mendapati bahawa rakan-rakan murid menyokong dalam kegiatan akademik, mengikut peraturan sekolah, mempunyai cita-cita yang tinggi dan murid cenderung memegang nilai dan kepercayaan bahawa sekolah ialah penting dan berguna bagi masa depan. Rakan-rakan merupakan sumber penting dalam mempengaruhi tingkah laku murid dan ibu bapa boleh menjalankan pengaruh kepada pembangunan persahabatan murid dengan rakan sebaya (Morton \& Chen, 2009). Sungguhpun begitu, dapatan kajian menunjukkan bahawa sokongan guru dan ibu bapa tidak memberikan sumbangan langsung terhadap pencapaian akademik. Berbeza dengan kajian lepas (Nye, Konstantopoulos \& Hedges, 2004; Wilson, 2009) yang mendapati bahawa sokongan guru dan ibu bapa mempengaruhi secara langsung pencapaian murid. Hal ini menunjukkan murid mempunyai pandangan bahawa pemantauan yang diberikan oleh guru dan ibu bapa terhadap pembelajaran mereka kurang bersesuaian bagi meningkatkan pencapaian. Terdapat pelbagai faktor yang boleh menjelaskan sokongan ibu bapa tidak menyokong pencapaian murid. Antaranya adalah faktor sosioekonomi keluarga dan tahap pendidikan ibu bapa. Kesan faktorfaktor tersebut telah dibukti dalam kajian Joe dan Davis (2009) dan Wilson (2009). 
Kajian lepas menunjukkan bahawa sokongan ibu bapa dan guru memberikan kesan langsung kepada keterlibatan murid (Chen, 2005; Morton \& Chen, 2009; Lam et al., 2012). Dapatan kajian ini mengukuhkan lagi kajian-kajian tersebut. Kajian ini menunjukkan sokongan guru dan sokongan ibu bapa merupakan penyumbang terhadap keterlibatan murid di sekolah. Sokongan ibu bapa mempunyai kesan langsung paling tinggi. Ini menunjukkan ibu bapa mampu mengawal keterlibatan murid di sekolah dengan memberikan motivasi dan kefahaman kepada murid pentingnya sekolah untuk masa depan. Ibu bapa menggalakkan murid untuk mengambil kelas tambahan dan membaca bahan-bahan pembelajaran di rumah. Sokongan guru pula adalah dalam membina iklim sosioemosi di sekolah dan menggalakkan keterlibatan aktif murid dalam aktiviti di sekolah. Walaupun demikian, dapatan kajian ini menunjukkan bahawa sokongan rakan kurang menyumbang kepada keterlibatan murid.

Dapatan kajian juga menyokong keterlibatan murid di sekolah sebagai perantara dalam hubungan antara sokongan daripada guru, ibu bapa dan rakan dengan pencapaian akademik. Dapatan ini adalah konsisten dengan kajian Li et al. (2010) dan kajian Chen (2005). Walaupun dapatan kajian ini menunjukkan bahawa sokongan guru dan ibu bapa secara langsung tidak memberikan sumbangan terhadap pencapaian akademik, melalui perantara keterlibatan murid, sokongan guru memberikan kesan terhadap pencapaian murid. Dapatan ini mengukuhkan kajian Ryan dan Patrick (2001), yang menunjukkan sokongan guru memberikan gangguan terhadap tingkah laku murid di sekolah sehingga mempengaruhi pencapaian akademik. Sokongan rakan menyumbang secara langsung dan tidak langsung terhadap pencapaian.

\section{RUMUSAN DAN IMPLIKASI}

Dapatan kajian ini telah menyumbang untuk meningkatkan kefahaman dan ilmu sedia ada terhadap faktor yang mempengaruhi pencapaian akademik dalam kalangan murid. Secara keseluruhan, murid lelaki adalah kurang terlibat di sekolah dibandingkan dengan murid perempuan. Perbezaan gender dalam keterlibatan di sekolah ini menerangkan sebahagian daripada jurang gender dalam pencapaian akademik. Peningkatan keterlibatan murid di sekolah memberi impak kepada kehadiran di sekolah dan pencapaian lebih baik, 
terutama bagi murid lelaki. Walaupun demikian, bagaimana untuk meningkatkan keterlibatan murid di sekolah adalah satu persoalan penting. Dapatan kajian ini dapat memberi arah tujuan bahawa untuk meningkatkan keterlibatan murid lelaki di sekolah adalah dengan meningkatkan sokongan daripada ibu bapa, guru dan rakan.

Ibu bapa memainkan peranan yang amat penting. Jika murid mempunyai persepsi bahawa ibu bapa prihatin dan mengambil berat terhadap mereka, peluang untuk keterlibatan di sekolah meningkat. Implikasi kajian ini menggalakkan pihak sekolah untuk mengadakan program intervensi yang melibatkan ibu bapa murid. Program ini dijalankan bertujuan untuk meningkatkan sokongan ibu bapa sebagai usaha menggalakkan keterlibatan murid di sekolah. Selain itu, implikasi kajian juga menggalakkan guru membentuk pembelajaran murid secara berkumpulan yang melibatkan murid lelaki dan murid perempuan. Ini merupakan satu bentuk tindakan dalam usaha untuk meningkatkan sokongan rakan dan memberikan kesan terhadap pencapaian akademik. Pihak sekolah perlu berkolaborasi secara berkesan dengan keluarga dan komuniti untuk meningkatkan keterlibatan murid di sekolah. Hubungan dua hala rumah-sekolah memberi kesan positif jangkaan ibu bapa, kepentingan pendidikan dan mengambil berat pembelajaran di sekolah menunjukkan sikap dan tingkah laku ibu bapa dan pihak sekolah membantu murid menghayati penglibatan di sekolah (Raftery, Grolnick \& Flamm, 2012).

Kajian ini mempunyai beberapa batasan. Data kajian dikutip secara keratan rentas dan dianalisis berdasarkan korelasi antara pemboleh ubah yang diukur. Cadangan kajian akan datang boleh meninjau sejauh mana pemboleh ubah yang diukur dipengaruhi oleh pemboleh ubah demografi seperti tahun pengajian murid, lokasi sekolah dan latar belakang keluarga. Satu aspek lain yang boleh dikaji adalah untuk meninjau keterlibatan murid di sekolah merentas perkembangan murid dari tahap kanak-kanak, awal remaja, pertengahan remaja dan akhir remaja. Kajian yang menumpu kepada ciri keterlibatan mengikut tahap perkembangan dapat meningkat kefahaman terhadap kaitan perubahan diri murid dan konteks serta sejauh mana proses perkembangan yang berlaku di rumah, sekolah dan kejiranan mempengaruhi keterlibatan murid di sekolah. Kajian yang mengkaji keterlibatan murid di sekolah merentasi tahap perkembangan memerlukan kaedah kajian berbentuk longitudinal yang masih berkurangan (Mahatmya, Lohman, Matjasko \& Farb, 2012). 
Kajian ini hanya mengkaji keterlibatan secara keseluruhan. Kajian lanjutan perlu memperincikan keterlibatan murid mengikut dimensi afektif, tingkah laku dan kognitif. Kesan setiap dimensi keterlibatan terhadap sokongan pembelajaran, gender dan pencapaian perlu dibincangkan dengan lebih teliti. Maklumat yang diperoleh dapat menyediakan garis panduan untuk tindakan yang lebih spesifik untuk mengurangkan jurang dalam pencapaian akademik murid lelaki dan perempuan.

Sebagai negara yang pesat membangun, Malaysia fokus dan komited untuk meningkatkan pencapaian serta hasil pendidikan dalam kalangan murid (Kementerian Pendidikan Malaysia, 2013). Jurang hasil pendidikan antara murid lelaki dan perempuan, di bandar dan luar bandar merupakan cabaran besar yang perlu ditangani. Pendidikan berkualiti adalah kunci untuk agenda pembangunan negara dan peningkatan mobiliti ekonomi dan sosial warga Malaysia. Dengan mengambil kira senario di atas, adalah penting untuk memahami faktor mempengaruhi pencapaian murid dalam kalangan remaja. Walau bagaimanapun, kajian perbezaan gender dan hubungannya dengan sokongan pembelajaran, keterlibatan murid dan pencapaian masih belum konklusif dan usaha untuk mencari penyelesaian berkesan perlu diteruskan.

\section{Penghargaan}

Data dalam kajian ini adalah sebahagian dari kajian Analisis Gender dalam Pendidikan di bawah geran penyelidikan Kementerian Pendidikan Malaysia. Penulis merakamkan sumbangan idea dan perkongsian ilmu dari dua orang Felo Pelawat Dana Endowmen Tengku Ampuan Afzan UKM, iaitu Profesor Peter Farrell (University of Manchester) dan Associate Professor Lam Shui Fong (University of Hong Kong).

\section{RUJUKAN}

Appleton, J. J., Christenson, S. L., Kim, D. \& Reschly, A. L. (2006). Measuring cognitive and psychological engagement: Validation of the student engagement instrument. Journal of School Psychology, 44, 427- 445. 
Appleton, J. J., Christenson, S. L., \& Furlong, M. J. (2008). Student engagement with school: Critical conceptual and methodological issues of the construct. Psychology in the Schools, 45, 369-386.

Archambault, I., Janosz, M., Fallu, J-S., \& Pagani, L. S. (2009). Student engagement and its relationship with early high school dropout. Journal of Adolescence, 32, 651-670.

Assor, A. (2012). Allowing choice and nurturing an inner compass: Educational practices supporting students' need for autonomy. In Sandy L. Christenson, Amy L. Reschly \& Cathy Wylie (Eds.), Handbook of research on student engagement (pp. 421-440). New York: Springer.

Ayodele, M. O. (2009). Gender differences in mathematics and integrated science achievement among junior secondary school students. Malaysian Journal of Learning and Instruction, 6, 41-53.

Baron, R. M., \& Kenny, D. A. (1986). The moderator-mediator variable distinction in social psychological research: Conceptual, strategic and statistical considerations. Journal of Personality and Social Psychology, 51, 1173-1182.

Bempechat, J., \& Shernoff, D. J. (2012). Parental influences on achievement motivation and student engagement. In L. Sandy Christenson, Amy L. Reschly \& Cathy Wylie (Eds.), handbook of research on student engagement (pp. 315-342). New York: Springer.

Benner, A. D., Graham, S., \& Mistry, R. S. (2008). Discering direct and mediated effects of ecological structures and processes on adolescents' educational outcomes. Developmental Psychology, 44, 840-854.

Bronfenbrenner, U. (1977). Towards an experimental ecology of human development American Psychologist, 32, 513-531.

Bronfenbrenner, U. (1989). Ecological systems theory. Annals of Child Development, 6, 187-249.

Byrne, B. M. (2010). Structural equation modelling with AMOS:

Basic concepts, applications and programming (2nd ed.). Multivariate Applications Series. New York: Routledge.

CDEG (Steering Committee for Equality between Women and Men). (2011). Combating Gender Stereotypes in Education. Retrieved from http://www.coe.int

Chen, J. J.-L. (2005). Relation of academic support from parents, teachers and peers to Hong Kong adolescents' academic 
achievement: The mediating role of academic engagement. Genetic, Social and General Psychology Monographs, 131, 77-127.

Croninger, R. G., \& Lee, V. E. (2001). Social capital and dropping out of high school: Benefits to at-risk students of teachers' support and guidance. Teacher College Record, 103, 548-581.

Darensbourg, A. M., \& Blake, J. J. (2014). Examining the academic achievement of black adolescents: Importance of peer and parental influences. Journal of Black Psychology, 40,191-212.

Darom, E., \& Rich, Y. (1988). Sex differences in attitudes toward school: Student self-reports and teacher perceptions. British Journal of Educational Psychology, 58, 350-355.

Dee, T. S. (2007). Teachers and the gender gaps in student achievement. The Journal of Human Resources, 42, 528-554.

Ding, W., \& Lehrer, S. F. (2007). Do peers affect student achievement in China's secondary schools? The Review of Economics and Statistics, 89, 300-312.

Eccles, J. S., Midgley, C., Wigfield, A., Buchanan, C. M., Reuman, D., Flanagan, C., Mac Iver, D. (1993). Development during adolescence: The impact of stage-environment fit on young adolescents' experiences in schools and in families. American Psychologist, 48, 90-101.

Epstein, D., Elwood, J., Jey, V., \& Maw, J. (1998). Failing boys: Issues in gender and achievement. Buckingham, PA: Open University Press.

Fall, A. M. \& Roberts, G. (2012). High school dropouts: Interactions between social context, self-perceptions, school engagement, and student dropout. Journal of Adolescence, 5, 787-798.

Finn, J. (1989). Withdrawing from school. Review of Educational Research , 5, 117-42.

Finn, J. D., Pannozzo, G. M. \& Voelkl, K. E., (1995). Disruptive and inattentive withdrawn behavior and achievement among fourth graders. The Elementary School Journal, 95, 421-454.

Fredericks, J. A., Blumenfeld, P. C., \& Paris, A. H. (2004). School engagement: Potential of the concept, state of the evidence. Review of Educational Research, 74, 59-109.

Freudenthaler, H. H., Spinath, B. \& Neubauer, A. C. (2008). Predicting school achievement in boys and girls. European Journal of Personality, 22, 231-245.

Furlong, M. J., \& Christenson, S. L. (2008). Engaging students at school and with learning: A relevant construct for all students. Psychology in the Schools, 45, 365-368. 
Furrer, C. \& Skinner, E. (2003); Sense of relatedness as a factor in children's academic achievement and performance. Journal of Educational Psychology, 95, 148-162.

Gerber, S. B., Finn, J. D., Achilles, C.M., \& Zaharias, J. B. (2001). Teacher aides and students' academic achievement. Educational Evaluation and Policy Analysis, 23, 123-143.

Hair F. J., Black W. C., Babin B. J., Anderson, R. E., \& Tatham, R. L. (2006). Multivariate data analysis (6th ed.). United States: Prentice Hall.

Hays, A. F. (2009). Beyond Baron and Kenny: Statistical mediation analysis in the new millenium. Communication Monographs, 76 (4), 408-420.

Hipkins, R. (2012). The engaging nature of of teaching for competency development. In Sandy L. Christenson, Amy L. Reschly \& Cathy Wylie (Eds.), Handbook of Research on Student Engagement (pp.441-456). New York: Springer.

Juvonen, J., Espinoza, G. \& Knifsend, C. (2012). The role of peer relationships in student academic and extracurricular engagement. In Sandy L. Christenson, Amy L. Reschly \& Cathy Wylie (Eds.), Handbook of Research on Student Engagement (pp. 387-403). New York: Springer.

Kementerian Pengajian Tinggi. (2012). Enrolmen pelajar di IPTA dan IPTS mengikut bidang pengajian 2010 dan 2011. Capaian daripada http://www.mohe.gov.my

Kementerian Pendidikan Malaysia. (2001). Kajian pencapaian akademik pelajar lelaki dan perempuan. Zalizan Mohd Jelas, Khadijah Rohani Mohd Yunus, Hazadiah Mohd Dahan \& Ma'rof Redzuan (Penyelidik), Laporan yang diserahkan ke Jabatan Pengajian Tinggi, Kementerian Pendidikan Malaysia. UKM: UKM Pakar runding.

Kementerian Pendidikan Malaysia. (2013). Pelan Pembangunan Pendidikan Malaysia 2013-2025. Dicapai daripada http:// www.moe.gov.my

Kelley, K. \& Preacher, K. J. (2012). On effect size. Psychological Methods, 17 (2), 137-152.

Kenny-Benson, G. A., Pomerantz, E. M., Ryan, A. M. \& Patrick, H. (2006). Sex differences in math performance: The role of children's approach to schoolwork. Developmental Psychology, 42, 11-26.

Lam, S. F., Jimerson, S., Kikas, E. Cefai, C., Verga, F. H., Nelson, B., Hatzichristou, C., Polychroni, F., Basnett, J., Duck, R., Farrell, P., Liu, Y., Negovan, V., Shin, H., Stanculescu, E., 
Wong, B. P. H., Yang, H. \& Zollneritsch, J. (2012). Do girls and boys perceive themselves as equally engaged in school? The results of an international study from 12 countries. Journal of School Psychology, 50, 77-94.

Li, Y., Lerner, J. V., \& Lerner, R. M. (2010). Personal and ecological assets and academic competence in early adolescence: The mediating role of school engagement. Journal of Youth and Adolescence, 39, 801-815.

Mahatmya, D., Lohman, B. J., Matjasko, J. L., \& Farb, A. F. (2012). In Sandra L. Christenson, Amy L. Reschly \& Cathy Wylie (Eds.), Handbook of research on Student Engagement. New York: Springer.

MCEETYA Gender Equity Taskforce, (1996). Gender equity framework for Australian schools. Retrieved from http:// www.mceecdya.edu.au

Morton, B. S. \& Chen, R. (2009). Peer and parent influences on school engagement among early adolescents. Youth \& Society Journal, 41, 3-25.

Nor Aniza Ahmad, Zalizan Mohd Jelas \& Manisah Mohd Ali. (2010). The relationship of learning styles and learning strategies with academic achievement between gender and type of school. International Journal on Learning, 17, 265-278.

Nor Aniza Ahmad, Zalizan Mohd Jelas \& Manisah Mohd Ali. (2011). The relationship of learning styles and strategies based on gender and type of school. International Journal of Learning, 17, 265-278.

Nye, B., Konstantopoulos, S., \& Hedges, L. V. (2004). How large are teacher effects? Educational Evaluation and Policy Analysis, 26, 237-257.

Perry, J. C., Liu, X. \& Pabian, Y. (2010). School engagement as a mediator of academic performance among urban youth: The role of career preparation, parental career support, and teacher support. The Counseling Psychologist, 38, 269-295.

Pianta, R. C., Hamre, B. K. \& Allen, J. P. (2012). Teacher-student relationships and engagement: Conceptualising, measuring and improving the capacity of classroom interactions. In Sandy L. Christenson, Amy L. Reschly \& Cathy Wylie (Eds.), Handbook of Research on Student Engagement (pp.365-386). New York: Springer.

Raftery, J. N, Grolnick, W. S. \& Flamm, E. S. (2012). Families as facilitators of stududent engagement: Toward a home-school partnership model. In Sandra L. Christenson, Amy L. Reschly 
\& Cathy Wylie (Eds.). Handbook of research on student engagement (343-364). New York: Springer.Reschly, A. L., \& Christenson, S. L. (2012). Jingle, jangle and conceptual haziness: Evolution and future directions of the engagement construct. In Sandra L. Christenson, Amy L. Reschly \& Cathy Wylie (Eds.), Handbook of research on student engagement New York: Springer.

Roeser, R., Eccles, J. S. \& Sameroff, A. J. (2000). School as context of early adolescent's academic and social-emotional development: A summary of research findings. Elementary School Journal, 100, 443-471.

Roorda, D. L., Koomen, H. M. Y., Spilt, J. L., \& Oort, F. J. (2011). The influence of affective teacher-student relationships on students' school engagement and achievement: A metaanalytic approach. Review of Educational Research, 81, 493-529.

Ryan, A. M. (2001). The peer group as a context for the development of young adolescent motivation and achievement. Journal Society for Research in Child Development, 72, 1135-1150.

Ryan, A. M. \& Patrick, H. (2001). The classroom social environment and changes in adolescents' motivation and engagement during middle school. American Educational Research Journal, 38, 437-460.

Ruban, L., \& McCoach, D. B. (2005). Gender differences in explaining grades using structural equation modelling. The Review of Higher Education, 28, 475-502.

Sharifah Azizah Syed Sahil \& Rosna Awang Hashim. (2011). The roles of social support in promoting adolescents' classroom cognitive engagement through academic self-efficacy. Malaysian Journal of Learning and Instruction, 8, 49-69.

Steinmayr, R., \& Spinath, B. (2008). Sex differences in school achievement: What are the roles of personality and achievement motivation? European Journal of Personality, 22, 185-209.

United States Agency for International Development (U.S.A.I.D.) (2005). A gender analysis of the educational achievement of boys and girls in the Jamaican educational system. Retrieved from http://pdf.usaid.gov

Waanders, C., Mendez, J., \& Downer, J. (2007). Parent characteristics, economic stress and neighbourhood context as predictors of parent involvement in preschool children's education. Journal of School Psychology, 45, 619-636. 
Wang, M. T., Willett, J. B. \& Eccles, J. S. (2011). The assessment of school engagement: Examining dimensionality and measurement invariance by gender and race/ethnicity. Journal of School Psychology, 49, 465-480.

Wang, M. T., \& Holcombe, R. (2010). Adolescents' perceptions of classroom environment, school engagement, and academic achievement. American Educational Research Journal, 47, 633-662.

Warrington, M., Younger, M., \& Williams, J. (2000). Student attitude, image and the gender gap. British Educational Research Journal, 26, 393-407.

Wentzel, K. R. (1999). Social-motivational processes and interpersonal realthionship: Implication for understanding students; Academic success. Journal of Educational Psychology, 91, 76-97.

Wentzel, K.R. (2005). Peer relationship, motivation, and academic performance at school. In A. Elliot \& C. Dweck (Eds), Handbook of competence and motivation. New York: Guilford.

Wentzel, K. R. (2009). Students' relationships with teachers ad motivational context. In K. Wentzel \& A. Wigfield (Eds.), Handbook of motivation at school. Mahwah, NJ: LEA.

Wilson, C. M. (2009). The relation among parental factors and achievement of African American urban youth. The Journal of Negro Education, 78, 102-113.

Woolley, M. E. \& Grogan-Kaylor, A. (2006). Protective family factors in the context of neighborhood: Promoting positive school outcomes. Family Relations, 55, 95-106.

Zalizan Mohd Jelas \& Hazadiah M. Dahan. (2010). Gender and educational performance: The Malaysian perspective. Procedia Social and Behavioral Science, 7, 720 -727.

Zalizan Mohd Jelas, Saemah Rahman, Roselan Baki \& Jamil Ahmad. (2005). Prestasi akademik mengikut gender. Jurnal Pendidikan, 30, 93-111. 